\title{
Phatic Rituals of the Liberal Democratic Polity: Hearing Voices in the Hearings of the Royal Commission on Aboriginal Peoples
}

\author{
JAMES SLOTTA \\ University of California-San Diego
}

\section{TRUTH AND RECONCILIATION, COMMUNICATION AND CONTACT}

Since the first truth commission was established in Uganda in 1974, they have become ubiquitous - in a recent count "there have been fourteen truth commissions proposed or established in Latin America, fourteen in Africa, six in Asia, two in Europe and Central Asia, and one in the Middle East and Northern Africa" (Weissbrodt and de la Vega 2007: 353). Though this is a fairly comprehensive list, the settler states of North America and Australasia are conspicuously absent. Since the 1990s, a number of first-world settler states have sought, through truth and reconciliation processes, reconciliation with indigenous peoples living on territory claimed by these states. These include national inquiries and commissions in Australia (the National Inquiry into the Separation of Aboriginal and Torres Strait Islander Children from Their Families) and Canada (the Royal Commission on Aboriginal Peoples and the Truth and Reconciliation Commission of Canada), and more recently on a smaller scale in the United States (the Maine Wabanaki-State Child Welfare Truth and Reconciliation Commission).

These bear many of the hallmarks of such processes in places like Latin America and South Africa, where efforts to "heal" the nation-state through testimonial practices have received more scholarly attention. In the view of a number of scholars, truth and reconciliation commissions are attempts to facilitate transitions "from a violent and authoritarian regime to democratic rule"

Acknowledgments: I would like to thank Michael Silverstein, Elizabeth Povinelli, Robert Moore, Alan Rumsey, Shunsuke Nozawa, Christopher Ball, and Alejandro Paz for their comments on an early draft of this article. Courtney Handman offered valuable suggestions on a number of drafts. I am especially grateful for the comments and suggestions of the editors, Andrew Shryock and David Akin, and the anonymous $\mathrm{CSSH}$ reviewers, whose thorough and insightful reviews improved the paper markedly and provided much food for thought. 
(Posel 2008: 120), through their attention to "transitional" or "restorative" justice, where personal or national "healing," and not merely the punishment of past wrongs, are desiderata (e.g., Kritz 1995; Minow 1998; Rotberg 2000; Teitel 2000). In contrast to "'transition' countries" in Africa, Latin America, and Eastern Europe, truth commissions in "“consolidated' Western democracies" (Bashir and Kymlicka 2008: 3) do not obviously fit such a model; Australia, Canada, and the United States are generally not considered "violent and authoritarian regimes," nor are the truth and reconciliation processes there seen to transition them to "democratic rule." But like truth commissions elsewhere, those in Canada and Australia are usefully viewed as attempts to transform social and political relations in the "consolidated" democracies of settler states, as rituals that exhibit a transformation of the body politic and delineate new terms in which the state and its citizens relate to one another. But what sorts of transformation do truth and reconciliation rituals in settler states work to bring about?

My argument, in brief, is that these rituals aim to establish a form of communicative contact - a kind of phatic communion (Malinowski 1923) - among citizens and agents of the state that realizes liberal and democratic ideals of communication. Participants in and commentators on these rituals pay considerable attention to what Roman Jakobson (1960) dubbed the phatic function of speech, its capacity to establish communicative contact between speakers and hearers, citizens and state, indigenous people and settler-dominated polity. ${ }^{1}$ As phatic rituals, truth and reconciliation hearings are framed as opening a channel of communication between the marginalized, the state, and other citizens where there was none before.

Here I look closely at the work of Canada's Royal Commission on Aboriginal Peoples (RCAP) to resolve a historical controversy over a relocation in the 1950s of Inuit families from Arctic Quebec to the far northern reaches of Canada. For over a decade these families had sought to be returned to their home communities in Quebec and to be compensated for the hardships they faced as a result of the relocations. In the 1980s, a number of them were returned to Quebec but at the time they received neither apology nor compensation. The Royal Commission took up the case in 1994 in an effort to reconcile those, including the government, who viewed the relocation as a well-

\footnotetext{
${ }^{1}$ Looking beyond the use of language in its representational capacity, Roman Jakobson took up Malinowski's term "phatic" to label "messages primarily serving to establish, to prolong, or to discontinue communication, to check whether the channel works ('Hello, do you hear me?'), to attract the attention of the interlocutor or to confirm his continued attention" (1960: 355). In general, the phatic function encompasses all manner of communicative contact between speaker and hearer. I do not mean to suggest by my use of this term that these rituals are solely phatic and that language functioning in representative, expressive, or any other capacity is irrelevant. I use this term merely to highlight this less discussed facet of truth and reconciliation processes.
} 
intentioned and largely successful effort to support struggling Inuit, and the Inuit families and political organizations demanding compensation.

Over and above their effort to arrive at the historical truth concerning the relocation and its effects on the Inuit relocatees, the Royal Commission framed its activities as a transformation of communicative relations within the body politic, ritually enacted in the truth and reconciliation process itself. More specifically, the Commission presented the process as giving the relocatees "a meaningful opportunity to tell their full story" (RCAP 1994: 4) after decades of being silenced and ignored, as a historical transformation in which illiberal communicative relations attributed to settler colonial pasts (e.g., being silenced or ignored by the state) give way through the truth and reconciliation process itself to a form of communicative contact characteristic of a more liberal democratic present.

The type of contact that the Royal Commission was at pains to enact strikingly resembles communicative ideals that have become a central element of much contemporary liberal democratic political theory: (1) communicative openness between citizens and the state; (2) equality of communicative opportunity; and (3) the ability to communicate freely, that is, without coercion. Taken together, these ideals delineate what could be termed a liberal communicative framework, an ideal type of communicative event realized in the hearings, at least according to how the Royal Commission and a number of prominent observers framed the ritual work being done. In this framing, the Commission hearings opened a communicative channel between previously unheard indigenous peoples and agents of the state, thereby equalizing the communicative opportunities of Inuit relocatees and Euro-Canadian officials. At the same time, the hearings created a context in which indigenous people were finally able to speak freely. This ritual of truth and reconciliation was presented as marking a break from a relatively illiberal past through the Commission's efforts to "liberate" the voices of indigenous peoples and create the conditions necessary for a liberal democratic form of phatic communion involving citizens and state alike. Such reconciliation efforts are, as Henderson and Wakeham point out, in part an effort "to shore up national mythologies of Canada's dedication to pluralism” (2013: 7). Here I will focus on the communicative dimension of this vision of Canada as, in the words of a Commission Report, "a special place — a place where human rights and dignity are guaranteed, where the rules of liberal democracy are respected, where diversity among peoples is celebrated" (RCAP 1996c: 3).

The controversy that developed over what was called the "High Arctic Relocation" gave rise to extensive commentary on the importance of testimony as a route to reconciliation. This provides us with a valuable lens on the communicative work being done in truth and reconciliation processes and the role of testimonial practices in liberal and democratic-oriented political life more generally (Sanders 1997; Schaffer and Smith 2004). As we will see, much has been 
written about the value of testimonial practices as part of efforts to arrive at reconciliation through truthful accounts of the past. But more than providing representations of the past, testimonial practices are usefully seen as exemplary enactments of the sort of liberal communicative framework I outline here, as indicative of a transformation of communicative relations in the body politic. In "giving voice" to those who have been "silenced" or "ignored," truth and reconciliation processes ritually incorporate them into liberal democratic communicative life, where having a "voice" is a crucial part of being a free and equal political being.

PLURALISM AND THE TURN TO COMMUNICATION IN LIBERAL

DEMOCRATIC THEORY

The importance of truth and truth-telling in the operation of truth and reconciliation commissions is obvious, if somewhat mysterious. Indeed, one curious aspect of such commissions is the connection they draw between political transformation and truth-telling. How is it that truthful testimony is linked to reconciliation and the renewal of the polity? A variety of institutionalized links between discourse, truth, and transformation color discussions of the work of truth and reconciliation commissions. Echoes of the psychological transformations wrought by psychotherapy can be heard, for instance, in the way one political scientist discussed the role of these commissions: "If societies are to prevent recurrences of past atrocities and to cleanse themselves of the corrosive enduring effects of mass injuries to individuals and whole groups, societies must understand - at the deepest possible levels - what occurred and why" (Rotberg 2000: 3; see also Minow 1998: 52-90). Christian confession and forgiveness provide another model for the transformative power of truth; after all, 'the notions of 'truth' and 'reconciliation' lie at the heart of ... the Christian tradition" (Botman and Petersen 1996: 12; see also Wilson 2001: 109-21). ${ }^{2}$ The truth being made public is seen as an essential prerequisite to the transformation of society, ranging in effect from the prophylactic ("preventing recurrences") to the performative ("cleansing"), and from the psychological ("providing closure") to the religious ("confessing"). ${ }^{3}$

In all of these perspectives, the work of truth and reconciliation commissions is bound up with the work of representation, of creating or expressing a truthful account of the past, or at least one that counts as truthful (Lerche 2000). But I argue here that an important and largely overlooked part of what is being done in these ritual events, especially in liberal, multicultural nation-states, goes beyond a concern with representation and truth. These commissions are concerned with establishing new conditions of communication between the

\footnotetext{
2 Therapy and Christian confession are of course not mutually exclusive as models (Posel 2008).

3 See Buur (2002) for another interesting connection between truth-telling and political transformation.
} 
people (especially minority groups) and the state - in particular, they enact an exemplary liberal democratic communicative event. As others have argued, truth and reconciliation processes ritually overturn the old order and legitimize the new (e.g., Henderson and Wakeham 2013; Teitel 2000; Wilson 2001), and here I focus on the communicative dimension of this ritual of transformation. In effect, liberal democratic forms of communication are presented as one element of what is needed to "heal" the nation-state.

The prominence of communicative concerns in contemporary liberal democratic politics is reflected in much current political philosophy. Discussions of communicative ethics, deliberative democracy, agonistic pluralism, and the like have placed communicative activities at the center of liberal democratic political theory, arguing that ideals of liberal democracy are realized in and by communicative activities such as argumentation (Benhabib 1996), deliberation (Gutmann and Thompson 2004), communication (Young 2000), dissent, disagreement, and contestation (Tully 2002), civil dialogue (Kingwell 1995), and testimony (Sanders 1997). "The fact of pluralism" has challenged the universality and neutrality of liberal democratic principles (e.g,. Taylor 1994 on liberalism as a "fighting creed"; Rorty 1991 on liberal "ethnocentrism"). Yet communicative practices offer hope that even if substantive political differences are fundamentally irreconcilable in pluralistic polities, communications about these substantive political matters will take forms that are widely accepted and in one way or another bear the hallmarks of liberal democratic principles (e.g., Ivison 2002; Parekh 2000; Tully 1995). In the words of Mark Kingwell, "What we shall find, in dealing with dialogic theories of justice, is that the focus of justice is actually shifted once more: away from particular norms and principles, to the conversational spaces in which they are generated and justified..." (1995: 8). Though agreement about "norms and principles" may be impossible in pluralistic polities, "conflicts and confrontations, far from being a sign of imperfection, indicate that democracy is alive and inhabited by pluralism" (Mouffe 2000: 34). Here, liberal democratic principles are phoenix-like: even if widespread consensus about the value of liberal democratic principles and norms is impossible, liberal democracy re-emerges as a set of political principles embodied in the very act of arguing about political principles!

Given the rich ethnographies of communication produced over the past several decades, it may seem dubious that communicative forms embodying liberal democratic principles are grounded in universal pragmatic presuppositions (Habermas 1979), or that they transcend social, cultural, and political differences in ways that more "substantive" issues of norms and principles do not. As we will see, indigenous peoples' claims to sovereignty pose a challenge to ideas that dialogue, argument, or contestation provide a widely acceptable, liberal democratic solution to the fact of pluralism. 
My aim here, though, is not to critique the views of political communication espoused in contemporary political philosophy. Rather, I have touched on the parochialism and partiality of these views as a starting point from which to develop a sort of ethnography of communication of contemporary liberal democratic institutions and rituals, examining how communication is "situated within and seen as meaningful in terms of native contexts of speech activity, i.e., culture-specific settings, scenes, and institutions in which speaking is done" (Bauman and Sherzer 1989: 7). Although the ideals of rational, critical, public sphere discourse set out by Habermas (1989) are not realized in "actually existing democracy" (Fraser 1990), the ideals of liberal democratic communications that he and others cited here have outlined do influence communicative practices in contemporary liberal democracies - they inform and give meaning to communicative practices and to "native contexts of speech activity." Rituals of truth and reconciliation are one context where these ideals are animated and the imagination of a liberal democratic polity constituted through particular forms of communication is made palpable.

If liberal democratic principles are seen to inhere in communicative practices such as truth and reconciliation hearings, we need to ask what sorts of communications count as embodying liberal democratic principles. There has been much debate about what genres of communication are essential to the realization of such principles (dialogue, argument, dissent, etc.), but across a number of different genres that have been discussed, a few features recur. These have less to do with the substance of what is said than the contextual conditions that render a communicative event liberal and democratic. To take one prominent example, "argument" as a discursive activity central to Habermas' vision of liberal democracy is defined with reference to several contextual features:

(i) that nobody who could make a relevant contribution may be excluded; (ii) that all participants are granted an equal opportunity to make contributions; (iii) that the participants must mean what they say; and (iv) that communication must be freed from external and internal coercion so that the "yes" or "no" stances that participants adopt on criticizable validity claims are motivated solely by the rational force of the better reasons. (1998: 44)

This brief list contains several contextual conditions that recur in discussions of liberal democratic communications, which I will take to delineate an ideal liberal communicative framework: (1) openness: the event is open to all citizens to act in the role of communicative participant ("nobody ... may be excluded"); (2) equality: there is an equality of opportunity to participate as communicator in the event ("all participants are granted an equal opportunity to make contributions"); and (3) freedom: participants are free of coercion when communicating in the event ("communication must be freed from external or internal coercion"). Openness, a central concern of democratic political theory, and equality and freedom, two pillars of liberalism, are here principles 
not merely of political relations, but of communicative relations understood as political.

Habermas and others have attempted to derive these conditions from a "transcendental pragmatics" (Apel 1990) or a "universal pragmatics" (Habermas 1979), and thereby provide a universal communicative grounding for liberal democracy. But as we will see, in the actual practice of communication what counts as "a relevant contribution," "coercion," "equal opportunity," and being "free" is open to a great deal of variation and debate. The nature of the context in which communications occur is not a pre-given reality, but is itself constituted (Duranti and Goodwin 1992; Silverstein and Urban 1996). In other words, communicative events are contextualized in ways that render them "open," "equal," and "free." Asserting or questioning the liberality of a communicative event is itself a significant political activity, one common in contemporary liberal democracies. What counts as a liberal communicative event is not something to be discovered by a "universal pragmatics," then, but something situated within a culturally, historically, and politically entrenched pragmatics. This is one reason an ethnography of communication is necessary here, to locate the ritual events and institutional settings that delineate, animate, and valorize liberal communicative events.

When philosophical discussions of communication in liberal democracies overlook the complex sociopolitical work that goes into contextualizing communicative events as open, equal, and free, they can mistake the products of institutional and ritual processes for clear-cut, objective features of communicative contexts. In this way, liberal communicative events are universalized and naturalized rather than situated within the cultural and political orders that delineate and valorize them. Truth and reconciliation rituals, I will argue, should be seen as part of this sociopolitical work, as they present the testimonies that take place under their roof as open, equal, and free, and contrast them with the communicative conditions that reigned "before."

The growing importance of communication in discussions of liberal democratic theory has mirrored increasing concerns about and attention to communication in liberal multicultural states, where communicative forums other than voting booths and opinion polls are seen as necessary to ensure that the "voices" of minority groups are heard. In the next section, I situate the Royal Commission on Aboriginal Peoples and the High Arctic Relocation controversy amid broader concerns about communications that emerged in Canada in the 1980s and 1990s. I look at how Aboriginal claims to rights and title at the time raised questions about whether courts were capable of "accommodating" the communicative forms, particularly the oral histories, that were essential to establishing Aboriginal rights and title.

In later sections, I scrutinize the Royal Commission's efforts to resolve the High Arctic Relocation controversy and to model a very different, non-judicial mode of communication with indigenous peoples, one that would bring a 
communicative openness, equality, and freedom that the Commission asserted had been lacking in the past. In these efforts, the oral testimony of Inuit relocatees was framed as the centerpiece of this ritual of reconciliation, as an exemplary liberal communicative event. Their testimony was portrayed as essential to establishing what really happened during the relocation, but the hearings were also depicted as "giving voice" to the relocatees, thereby transforming communicative relations between them, other Canadian citizens, and agents of the state.

FAILURES OF COMMUNICATION IN LATE TWENTIETH-CENTURY

CANADA: THE CASE OF ORAL HISTORY

In March of 2001, an open letter from Canada's Prime Minister Jean Chrétien was read at the opening ceremonies of the first Indigenous Peoples Summit of the Americas. "For too long," Chrétien observed, "the voices of Aboriginal peoples have not been heard in the councils of government or in the management of their own economic, social and cultural affairs," and he vowed to bring concerns attendees raised to the attention of heads of state when they attended the Summit of the Americas the next month (in Mofina, Jaimet, and Korah 2001).

The failure to listen has been a recurring theme in discussions of the relations between the Canadian state and First Peoples. It was a prime complaint of the Indian Chiefs of Alberta concerning the "Statement of the Government of Canada on Indian Policy," a White Paper that Chrétien himself unveiled in 1969 while he was Minister of Indian Affairs and Northern Development. In a document that galvanized indigenous political organizing in the 1970s, the Indian Chiefs of Alberta rejected this statement, which proposed to abolish both the Indian Act and the special legal relationship between Aboriginal peoples and the state. The Chiefs wrote that they had been "stung and hurt by [the Federal Minister of Indian Affairs'] concept of consultation" (Indian Chiefs of Alberta 2011 [1970]: 189): "No Treaty Indians asked for any of these things [proposed in the White Paper] and yet through his concept of 'consultation,' the Minister said that his White Paper was in response to things said by Indians" (ibid.: 190).

Over the next two decades, a variety of forums emerged for listening, consultation, and negotiation between indigenous people and the state, ranging from the extensive hearings of the Mackenzie Valley Pipeline Inquiry (19741976; Berger 1977) to the land claim negotiation process that arose from the recognition of Aboriginal title in the 1973 Calder case. But in the late 1980s and early 1990s, the Canadian mosaic was unsettled by a series of events that brought the disaffection of indigenous people to public attention. Among the issues were continuing concerns about communications between indigenous people, the state, and others in Canada. In 1990, a proposed set of amendments to the Canadian Constitution known as the Meech Lake 
Accord was rejected due in large part to the opposition of indigenous groups, who objected to being excluded from the negotiation process. That same year, news coverage focused on the Oka crisis, a nearly three-month armed standoff between Mohawk Warriors and police and the Canadian Armed Forces at Kanehsatake and Kahnawake outside of Montreal. The crisis was prompted by plans to expand a private golf course onto land long claimed by the Mohawk, a claim the Office of Native Claims had rejected in 1986. In the end, the golf course was not built and although the standoff did not resolve the Mohawk's claim it did focus public attention on First Nations' concerns: "I look at Oka as a victory, a victory for native rights," said Kenneth Deer, editor of the Mohawk newspaper the Eastern Door. "In the end, the governments had to listen to us" (in Ha 2000).

Soon after this, the 1991 decision in the case of Delgamuukw v. British Columbia rekindled tensions between the state and indigenous groups. During 318 days of testimony, members and elders of the Gitksan and Wet'suwet'en nations supported their claim to Aboriginal title to over 58,000 square kilometers of land in British Columbia. In the end, Chief Justice McEachern of the Supreme Court of British Columbia dismissed the plaintiffs' claims to Aboriginal title, self-government, and Aboriginal rights. Weighing the oral traditions they presented in support of their claim, he commented, "If I do not accept their evidence it will seldom be because I think they are untruthful, but rather because I have a different view of what is fact and what is belief." "As in Mashpee Tribe v. New Seabury et al., as described by James Clifford, "The written archive had more value than the evidence of oral tradition, the memories of witnesses, and the intersubjective practice of fieldwork" (1988: 341).

A vocal audience of academics and activists was troubled by the lack of consideration given to the oral historical evidence. In their view, the rules and weighing of evidence particular to Western understandings of evidence and history posed an existential threat to Aboriginal rights and rendered the courts an exclusionary, ethnocentric forum (e.g., Asch and Bell 1994; Borrows 2001; Fortune 1993; Monet and Skanu'u 1992). After hearing the case on appeal in 1997, the Chief Justice of the Supreme Court of Canada raised many of the same concerns in his majority opinion, and ultimately found that a new trial was warranted. He reasoned that in Aboriginal rights cases both the application of the rules of evidence and the interpretation of that evidence "demand a unique approach to the treatment of evidence which accords due weight to the perspective of aboriginal peoples" (Delgamuukw $v$.

\footnotetext{
${ }^{4}$ Quoted in part 7 of "Reasons for Judgment of the Honourable Chief Justice Allan McEachern, Delgamuukw v. British Columbia, 1991, CanLII 2372 (BC SC)." At: $<$ http://canlii.ca/t/1g2kh $>$ (accessed 16 July 2014).
} 
British Columbia [1997] Supreme Court Review, vol. 3, par. 82, at: <http:// canlii.ca/t/1 fqz8> (accessed 16 July 2014$)^{5}$ :

Notwithstanding the challenges created by the use of oral histories as proof of historical facts, the laws of evidence must be adapted in order that this type of evidence can be accommodated and placed on an equal footing with the types of historical evidence that courts are familiar with, which largely consists of historical documents.... To quote Dickson C. J., given that most aboriginal societies "did not keep written records," the failure to do so would "impose an impossible burden of proof" on aboriginal peoples, and "render nugatory" any rights that they have... (ibid.: par. 87).

As hearsay, oral history is at odds with the laws of evidence, and as "woven with history, legend, politics and moral obligations" it is at odds with "the ultimate purpose of the fact-finding process at trial - the determination of the historical truth" (ibid: par. 86). Nonetheless, the Supreme Court found that Aboriginal rights and title are dependent on and motivate the acceptance of Aboriginal oral histories as a form of communication with a special status in the courts.

The Delgamuukw decisions and the responses of activists, academics, and others underscored the communicative challenges that Aboriginal claims to rights and title faced in Canadian courts, and raised questions about whether Canadian courts were venues where Aboriginal voices could be "heard" and thereby placed on an equal footing. Even as the Supreme Court decision insisted that oral histories had to be accepted as evidence, it noted that such a special communicative right poses a serious challenge: "Aboriginal rights are truly sui generis, and demand a unique approach to the treatment of evidence which accords due weight to the perspective of aboriginal peoples. However, that accommodation must be done in a manner which does not strain 'the Canadian legal and constitutional structure' (Van Der Peet, at par. 49)" (Delgamuukw v. British Columbia 1997, par. 82).

Though this decision declared that the oral histories and the perspectives of Aboriginal peoples must be given weight in Canadian courts, it did not spell out in any generally applicable way how this special communicative right should be accommodated. Moreover, as Dale Turner points out, this special communicative right was subordinated to the Canadian legal and constitutional structure; "the Supreme Court, once again, constrained aboriginal voices" (2013: 107).

The same year that Chief Justice McEachern issued his decision in Delgamuukw, the Royal Commission on Aboriginal Peoples was established with a broad mandate to "examine all issues which it deems to be relevant to any or all of the aboriginal peoples of Canada" (RCAP 1996a: 12). As part of its efforts it elicited the input of people across the country, and provided a venue in which

\footnotetext{
5 CANLII is the Canadian Legal Information Institute, and interested readers can find the decisions cited here published on their website: canlii.org.
} 
citizen and state, First Peoples and Euro-Canadians, could communicate on terms very different from those in the courts, absent the rules of evidence and considerations of "the Canadian legal and constitutional structure." Through a series of "consultations" held across the country, the Commission presented an alternative, non-judicial model of communications that was explicitly designed to be open:

Public consultation played a significant role in our process. The Commission's work was concerned largely with people - their lives, their goals and their dreams - so we wanted to pay particular attention to the voices and ideas of the people concerned. We wanted to hear what they had to say about everything in our mandate and made a deliberate choice not to set limits on the issues that could be raised.... To the greatest degree possible, we went wherever we were invited, recognizing the need to meet with as broad a crosssection of Canadians as possible... To keep the process as open as possible, we began by listening to what people at the grassroots had to say. We felt that options and solutions had to emerge from consensus among Aboriginal people if our eventual recommendations were to command broad support and acceptance.... Over the four rounds of hearings, we listened to Canadians - Aboriginal and non-Aboriginal alike - in friendship centres, community halls, penitentiaries, band council offices, traditional long houses, schools, women's shelters, and hockey rinks, as well as in hotels and conference centres.... By the end of the fourth round, in December 1993, we had visited 96 communities (some of them more than once), held 178 days of hearings, heard briefs or statements from some 2,067 people representing organizations, communities or associations or speaking on their own behalf, and generated 75,000 pages of transcribed testimony (RCAP 1996b: 262-63).

This elaborate consultation process itself was put forward as part of the process of reconciliation: "The starting point for renewing the relationship, urged upon Commissioners by Aboriginal people speaking to us in hearings across the country, must be deliberate action to "set the record straight"' (RCAP 1996a: 16). This required giving due weight to "Aboriginal people's view of themselves and their encounters with settler society," a perspective that "the official record of Canada's past_recorded in government documents, in the journals and letters of traders and colonial officers, in history books and in court judgments - ignores and negates" (ibid.).

By creating conditions of communicative openness, equality, and freedom, the hearings set out to begin a process of reconciliation that had proved difficult in the courts, which were struggling to give "due weight to the perspective of aboriginal peoples." The High Arctic Relocation hearings were some of the most widely publicized and the most controversial hearings held by the Royal Commission, and they offer a particularly useful window into the communicative work the Commission set out to accomplish as a way to remedy the failures of communication in late twentieth-century Canada. Before I turn to the Commission's work, I need to provide some background regarding the relocation and the controversy that arose from it. 
A HISTORY OF HISTORIES: THE HIGH ARCTIC RELOCATION

CONTROVERSY

I know the files of the present Department of Indian and Northern Affairs seem depleted of these details. With all the reorganization, I guess files go astray or are destroyed. It is sad that as we live through an era, so many people are not conscious that it is history in the making no matter how seemingly uneventful the events may be. Someday researchers may wish to fill in the gaps and I hope my small contribution will be useful (Alexander Stevenson, in Hammond 1984).

In 1977, Alexander Stevenson appended this prophetic comment to his brief history of the High Arctic Relocation, a relocation that the participating administrators, including Stevenson, had long considered a success, even if one worthy of only a footnote in Canadian Arctic history. As it happened, this "uneventful" story of seventeen Inuit families relocated from their home region to unsettled areas in the distant north became the subject of over ten histories and a topic of discussion on national radio programs, televised documentaries, editorial pages, and even a special section in the Ottawa Citizen (5 Mar. 1994).

All of the histories give an account of the relocation similar to the following. In the summer of 1953, seven Inuit families boarded a patrol ship in northern Quebec at Inukjuaq/Port Harrison bound for three new settlements in the High Arctic, over 1,000 miles to the north. En route three more families were taken on at Mittimatalik/Pond Inlet, a settlement on northern Baffin Island. On 29 August, the ship reached the Royal Canadian Mounted Police (RCMP) detachment at Craig Harbour on Ellesmere Island, where four families disembarked, and formed the settlement of Grise Fiord. The other families boarded an icebreaker headed for a new RCMP detachment at Alexandra Fiord, the northernmost detachment in Canada. The ship was halted by heavy pack ice on the way, and so returned to Craig Harbour, where two more families disembarked. It continued on to Resolute Bay, where the remaining four families were landed on 7 September. In 1955, seven more families relocated from Inukjuaq and Mittimatalik to these High Arctic settlements.

Following the development of Inuit political organizations in the 1970s, the Makivik Corporation, an Inuit organization in Northern Quebec, and the Inuit Tapirisat of Canada (ITC), a national Inuit organization, began lobbying on behalf of the relocatees in an effort to secure government assistance in returning them to Inukjuaq. The Department of Indian Affairs and Northern Development (DIAND) responded in 1984 by commissioning Marc M. Hammond to determine whether the government had promised to finance the return of the relocated Inuit to Inukjuaq if they requested it. He found that such a promise had indeed been made and that "the Inuit had grounds to call in the promise" and "apparently they have tried to do so repeatedly since $1956 \ldots$... No one seems to have listened" (Hammond 1984).

Over the next several years, the Makivik Corporation discussed compensation with the government and the relocatees, resulting in DIAND agreeing to 
pay $\$ 200,000$ to finance their return to Inukjuaq, and to build new housing for them there. In a letter to the minister of DIAND in 1989, Makivik requested, among other things, a Heritage Trust Fund of $\$ 10$ million be set up to compensate the original seventeen families, "similar to the symbolic redress payments presently being made by the Government of Canada to Japanese Canadians who were subject to internment" (in Gunther 1992: 395). The government rejected this, however, claiming that the issue had been settled.

With the government refusing to negotiate, seven relocatees presented testimony before the House of Commons Standing Committee on Aboriginal Affairs in 1990. The Committee recommended, among other things, "the Government make an apology for the wrongdoing which the government inflicted on the people of Grise Fiord and Resolute Bay" and "consider compensation to the people of Grise Fiord and Resolute Bay for their service to Canada and the wrongdoing inflicted upon them" (Hickling Corporation 1990: 2). The government response to these recommendations, based on a report commissioned by DIAND and prepared by the Hickling Corporation, claimed that the Inuit people were relocated "to assist them in continuing to follow their traditional livelihood through greater access to game resources" (in Gunther 1992: 397). The Hickling report goes on, "We do not see the grounds for an apology by the government for the manner in which the relocation project was conceived, planned and carried out. To apologize for a wrongdoing it did not commit would constitute deception on the part of the Government and would imply that the project was a failure, when, in fact, it was a reasonably successful endeavour" (1990: 57).

When Makivik and ITC requested that the prime minister intervene in the matter, the minister of DIAND responded, "No responsible government would or should make public apologies and compensation based solely on memories or recollections of events which had occurred so long ago" (in Gunther 1992: 398). Meanwhile, several other reports were in preparation that supported the relocatees' claims: Daniel Soberman, a professor of law, prepared one for the Canadian Human Rights Commission (Soberman 1991); Alan Marcus published a history of the relocation, originally his MA thesis, with the International Working Group on Indigenous Affairs (Marcus 1992); and Shelagh Grant, a historian of the Canadian North, published a history in Northern Perspectives, the journal of the Canadian Arctic Resources Committee (Grant 1991). In January of 1992, both the minister of DIAND and representatives of the ITC expressed satisfaction with the Soberman report, claiming that it validated their views. The minister of DIAND noted that the report recognized "that the primary motivations for the project were humane" (in RCAP 1994: 182). The ITC, on the other hand, highlighted Soberman's finding that the relocatees suffered unnecessary hardship caused by inadequate planning and implementation of the project, and that this was due to a failure of the government to meet its fiduciary duties to the Inuit as mandated in Canadian law. Differences arose 
over the proper reparations, as bluntly stated in a 16 January 1992 headline in the Toronto Star: "Inuit Want Cash, not Apology."

Adding to the growing controversy, in November of 1992 the minister of DIAND tabled the government's second response to the Standing Committee on Aboriginal Affairs, this one based on a report commissioned by DIAND and written by the political scientist Magus Gunther. The government admitted that despite its good intentions, and though the move had improved the relocatees' economic circumstances, the project's preparation and implementation had been deficient. The government offered to continue to relocate, house, and pay for visits of relocatees back to Inukjuaq, but said that additional compensation was "not contemplated" (Gunther 1992: 400). The ITC responded that this stance and the report it was based on were "vicious and insulting," and noted that Gunther "boasts that he consulted over 9,000 government documents, but there is no indication that he ever interviewed or consulted a single Inuk" (in Grant 1993: 7).

In December, the ITC wrote to the co-chairs of the recently established Royal Commission on Aboriginal Peoples (RCAP) stating that more extensive testimony from the relocatees was required. The Commission agreed to mediate the High Arctic Relocation dispute, and in April of 1993 heard four days of testimony from the relocatees. In June and July, the Commission heard another four days of testimony, this time from former officials involved in the relocations and the researchers who had written reports or histories of the events. In 1994, the Commission released its report, the tenth history (at least) of the relocation written since Stevenson's paper. The report found:

The Department [of Mines and Resource] proceeded with the High Arctic relocation without proper authority. The relocation was not voluntary. It proceeded without free and informed consent. There were material misrepresentations, and material information was not disclosed. The true nature of the relocation - that is, a rehabilitation projectand the inherent risks were not disclosed.... Moreover, many Inuit were kept in the High Arctic for many years against their will when the government refused to respond to their requests to return. The government was negligent in its planning and implementation of the relocation.... The relocation was an ill-conceived solution that was inhumane in its design and its effects... The government, in the final analysis, failed in its fiduciary responsibilities to the relocatees (RCAP 1994: 162).

A New York Times book review of yet another history of the relocation stated, "At its conclusion, the Royal Commission on Aboriginal Peoples called the relocation 'one of the worst human rights violations in the history of Canada.' The country was shocked by the abuse and arrogance of its leaders, who eventually made financial reparations of 10 million Canadian dollars to the survivors and their families. But the government has yet to apologize" (Royte 2007). In 2010, Minister of Indian Affairs and Northern Development John Duncan issued a formal apology. 
GIVING VOICE: TRANSFIGURING SPEECH INTO VOICE THROUGH THE FREEDOM OF THE ARCHIVE

Concerns about communication echo throughout the High Arctic Relocation controversy. The complaint that a historian commissioned by the Canadian government "consulted over 9,000 government documents, but there is no indication that he ever interviewed or consulted a single Inuk" insinuates that the government had ignored the Inuit relocatees' voices. The statement that the relocatees had been seeking repatriation to Arctic Quebec for decades but "No one seems to have listened" points to the long duration of this communicative failure. The criticisms of the government centered not only on the relocation itself but also on the way it had handled the Inuit complaints and requests during and after the relocation. The Royal Commission on Aboriginal Peoples presented itself as a venue where these failures of communication could be remedied and the Inuit relocatees' voice would finally be heard.

Like many other cases involving indigenous people and other minority groups, a central concern in the High Arctic Relocation controversy was voice. "Giving voice" to the voiceless, "hearing the voice" of the silencedthese have become important political, historiographic, and juridical activities in the late twentieth and early twenty-first centuries. Voice as a property of individuals and collectives can be silenced or heard, given, appropriated or recuperated. Giving voice and hearing voices contrasts with the absence of voice, an undemocratic and illiberal communicative condition (e.g., Couldry 2010; Schlozman, Verba, and Brady 2012). Voice is intimately connected with the principles of liberal democracy, government guided by the "voice of the people," which at the same time guarantees freedom of expression to "dissident voices." Elections, the public sphere, the fourth estate, and other rituals and institutionalized modes of communication among citizens and the state are the infrastructure for a polity composed of voices (Fishkin 1995; Norris and Zinnbauer 2002), one built on and imagined through the effective expression of personal and collective perspectives and interests.

Though giving voice is often presented as a straightforward matter-one of letting the silenced speak - the High Arctic Relocation controversy reveals some of the contextualizing work that goes into constituting an instance of speech as one that evinces a speaker's true voice. In this case, historians and others who challenged the Inuit relocatees' accounts of the relocation claimed to be re-presenting the "true" voice of the relocatees. That is, those arguing against the claims of the Inuit relocatees claimed to be "giving voice" to the relocatees, a voice that was at odds with what the relocatees themselves were saying. This seems paradoxical, given that voice seems intimately connected to the speaking subject. How could historians give voice to the Inuit relocatees in a way that contradicts what those very relocatees were saying? 
Let me provide one example, the most striking instance where historians and others set the "true" relocatees' voice(s) in contrast to what the relocatees themselves were saying. Among the most important pieces of evidence for those challenging the relocatees' claims were a number of letters relocatees had written at Resolute Bay, dating from the mid-1950s through the early 1960s. In many of these the authors say they are satisfied with their new home, and they often ask whether more family members can be brought from Quebec to join them. These letters, the Hickling report states, are "[p] erhaps the strongest evidence" of "the abundance of game and the general satisfaction with living conditions in the Craig Harbour/Grise Fiord and Resolute Bay areas" (Hickling Corporation 1990: 32). The report construes these positive evaluations of the relocation in the letters as an authentic expression of the Inuit relocatees' voice. In the words of Gerard Kenney, who worked for Bell Canada in the Canadian North in the 1960s and wrote a book on the relocation, the letters were "spontaneously written by adult Inuit in the 1950s and 1960s.... [They] had no possible hidden agenda but ... are a true and innocent expression of the writers' feelings and opinions.... [They] are not written to influence any potential $\$ 10$ million prize ... [and] were not subject to any peer pressure. These were individual and private initiatives. No lawyers were involved..." (RCAP 1997: 6582/11244). In the Toronto Star, author Pierre Berton trumpeted Kenney's then unpublished book in which he presents a number of such arguments, writing, "There are signs that some Inuit were coached in their later testimony. One was heard to confess that 'we were told to say bad things.' Another: 'I got tired of rehearsing....' As Kenney points out, 'peer pressure is a powerful agent of distortion. So is the possibility of a $\$ 10$ million windfall"” (1994).

Kenney and others privileged these letters over the oral testimony of the relocatees for a number of reasons. For one, they were written at the time of the relocations and are thus not subject to retrospective reevaluation or the fallibility of memory. As Kenney's commentary makes clear, they are valued also because they were produced in a relatively "free" communicative context, and the archived letters record what appears to be a quintessentially liberal communicative event: they are "individual" and "private," "not subject to peer pressure," and have "no possible hidden agenda." They are free communications, free of distortions and coercion by external influences (see Habermas' condition iv, above). As such they are, in Kenney's evaluation, "a true and innocent expression of the writers' feelings and opinions."

In this framing, voice is something that emerges when social and political constraints or distorting influences are lifted, when people are free to speak. Under conditions of freedom, mere speech can be transfigured into voicethat is, a true, authentic expression of the views of a speaking subject. Viewed as speech free from social and political constraints - as minimally contextualized speech-voice appears as the natural expression of the liberal 
self-determining (Taylor 1992) and possessive individual (Macpherson 1962), in possession of opinions, interests, and perspectives which they express uninfluenced by others. From this perspective, voice is speech in the state of nature.

By framing voice in negative terms, as that which emerges when speech occurs without social and political constraints, voice appears to be natural, minimally contextualized speech. Only speaker and speech coexist in this frame. It is therefore easy to overlook the positive contextual conditions that make a speech event count as free in any particular situation. What counts as a context free of coercion, one where communicative freedom is possible?

For Kenney and others, "free," un-coerced speech was found in archival documents, not the oral testimony of the relocatees. In fact, the testimony was given in a context that was anything but free, according to Kenney. "Prizes" of $\$ 10$ million were coercive, and in this view they influenced people's speech, rendering it something less than a free expression of the relocatees' true voice.

Kenney was not alone in valuing archival sources over oral testimony as a source of voice. In contrast to oral histories presented in contexts of "interested" activity, archival documents can take on an aura of disinterestedness and relative communicative freedom. The modern bureaucratic archive (ideally) temporally and otherwise divorces the inscription of documents during the course of bureaucratic business from the reading of them in an archival reading room. At this distance, the reader becomes an over-hearer of an inscribed communicative event, unknown and unknowable to the participants in the interaction. This distance between inscription event and the reading event situates the reader in a way analogous to an observer in a laboratory experiment, whose presence does not interfere with the behavior of the objects being observed. ${ }^{6}$ As the historian Marc Bloch termed the best historical evidence, the messages in an archive are often "witnesses in spite of themselves" (1953: 61). They were not written to witness to the future because they were written in and for a presumably very different immediate context. These contexts can appear relatively "private" or "offstage," in contrast to contemporary

${ }^{6}$ The temporal and more generally the contextual distance between inscription event and reading event lends archival documents qualities of, in the words of two archivists, "impartiality and authenticity": "Archival science is based entirely on the concept of records-that is, traces that are generally in written form created and accumulated by individuals or institutions in the normal course of their activities. The documents bear witness to actions and transactions between the parties involved, whence their evidential value. They are produced spontaneously to serve purposes proper to their creator(s), to guarantee rights and record decisions, not with a view to informing posterity. Owing to the 'organic' or 'natural' nature of their creation, they acquire qualities of impartiality and authenticity that make them reliable evidence with respect to the action and transactions with which they are connected and that gave rise to them" (Wallot and Fortier 1998: 365-66, my emphasis). From this perspective, archival documents are imbued with qualities of impartiality and authenticity - recording an objective independent reality, uncompromised by observer effects - through the institutional regimentation of their circulation in an archive. Of course, people sometimes do in fact compose documents with future readers in mind. 
claims hearings, where rights and reparations are at issue. In what appears to be the relatively private arena recorded in documents, people are not performing for anyone, and they express their true voice.

Oral histories stereotypically have few of the qualities that lend archived documents an aura of disinterestedness. For one, oral histories are spoken in contexts that are conspicuously interest-laden. People's interests in compensation, rights, and title can be seen as a source of coercion that distorts their recollection of events whether consciously or unconsciously. Many have noted the challenge indigenous claimants face in presenting an authentic indigenous voice in the conspicuously interested context of claims hearings (e.g., Merlan 1998; Povinelli 2002). Archived documents, in contrast, can appear to offer an unconstrained, undistorted, "liberal" expression of an indigenous perspective, a contextualization of archival documents that Gerard Kenney and others were at pains to point out in the High Arctic Relocation controversy. $^{7}$

Though the voicing of the Inuit perspective in the letters is represented as free-from interests and other sources of distortion-it is hardly context free. The elaborately institutionalized contextualization of archival documents in modern bureaucratic archives lends these documents an aura of communicative freedom for some people. Furthermore, Kenney and others explicitly contextualize the archival documents they draw on, highlighting contextual features that lend the letters an aura of freedom.

Giving voice, then, is not merely a matter of allowing the Inuit to speak. It is a matter of contextualizing a communicative event such that it counts as free, and what counts as "free" is a political and cultural matter. That is to say, how people construe contexts as free is variable, contested, and subject to historical change. For opponents of the relocatees' claims, the archive provided one very important context where the true voice of the Inuit subject could be found. In contrast, the Royal Commission challenged these archival sources and their aura of relative freedom, and instead presented oral testimony as a context relatively free of coercion, one in which the relocatees' voice could be heard.

DECONSTRUCTING VOICE: THE COMMUNICATIVE ILLIBERALITIES OF CANADA'S PAST

The Royal Commission on Aboriginal Peoples' attempt to resolve the High Arctic Relocation controversy was in part an effort to craft an approach to indigenous claims that was open and equal, and would allow everyone involved a chance to speak and be heard. For those challenging the Inuit claims, a lack of communicative openness, equality, and freedom had not been a serious problem in the relocation. Archival sources in their view provided evidence

\footnotetext{
7 See Povinelli's account of how the desire for archival sources overtakes Belyuen claimants themselves (2002, ch. 5).
} 
that the Inuit voice had spoken and government officials had listened back in the $1950 \mathrm{~s}$.

The Royal Commission, however, framed communications between the Inuit and government officials in the 1950s as fundamentally illiberal. It held eight days of hearings in which the testimony of the relocatees was heard along with that of others, including individuals who had been government officials at the time of the relocation, historians who had written about the relocation, and anthropologists familiar with conditions in the Arctic at the time. The centerpiece of this ritual of communicative liberalization was the four days of televised hearings devoted to the testimonies of the Inuit relocatees. But much of the work required to contextualize that moment was accomplished during the non-Inuit testimonies that followed.

For instance, the Royal Commission's contextualization of communications between the government and the Inuit in the 1950s drew on anthropologists' discussions of the Inuit. One, Hugh Brody, offered the following account of the Inuit in the 1950s and how they viewed interactions with whites:

However much one came to like and trust and joke with and travel with and have sociability with one of the local whites ... one never lost site of the fact that they were the end of a long line of distant authorities with objectives and agenda which were perhaps not fully known and not entirely predictable ... but the tendency usually, by and large, in those days was for an inference of intention, an exploratory inquiry to be interpreted by the Inuit as something rather more executively impelled having more the power of, if not an order, at least a desire that it would be in one's best interests to take very seriously and, if at all possible, accept (in RCAP 1994: 13).

The Royal Commission drew on Brody's account to bring into question Kenney and others' construal of the relocatees' letters: was the affable, agreeable face put forward by the Inuit in the 1950s and recorded in the archival documents by Euro-Canadian administrators a distortion of the true Inuit voice? Were the archival accounts of what the Inuit said to officials actually coerced and "unfree"? Were the Inuit unable to "question what the authorities presented to them as an apparent choice" given that "the feelings that whites inspire in Inuit is a kind of fear, a blend of awe and intimidation, the feeling you have about a person whose behavior you can neither control nor predict, but who is perhaps going to be dangerous" (Cairns 2003: 21, quoting the RCAP report on the High Arctic Relocation)?

In reviewing the relocatees' letters that had been presented as evidence of Inuit satisfaction following the relocation, the Commission noted that the Inuit might have been unable to voice their true feelings. The Commission focused on the communicative context in which the letters were written: "Several of the letters are from people requesting that relatives join them at Resolute Bay, giving assurance that there is lots of game to support more people. In this regard, the relocatees can be seen to be seeking to address the concern of government officials about the adequacy of game. If they were not successful in 
persuading officials that there was enough game, their desire to be reunited with their families might be frustrated" (RCAP 1994: 112). The following portion of a letter quoted in the Commission's report certainly can be construed in this way: "I want you to write to me if I am going back to Port Harrison. I will be thankful if I can go. My wife's father lives at Port Harrison and he is very old. I want to go back for a while next summer. I still want to go hunting this winter at Resolute. I am able to live anywhere-Port Harrison or Resolute Bay. If the Eskimos' boss doesn't mind. I will be happy. Even if he refuses, I won't mind. Because I can't do anything myself. I can only do anything if the white people help me. I know that white people help me a lot - all of them" (in ibid.: 112). Does this letter indicate that this relocatee was happy in Resolute, or rather that they could not express their true voice when speaking with administrators?

In the reading of the archival documents offered by the Royal Commission, the letters did not record the voice of the Inuit relocatees because their speech was distorted by a coercive communicative context. If the archival documents recorded any voice, it was that of Euro-Canadian government officials. In the Commission's words, they recorded the "sincere belief" of government officers that the Inuit were happy with the relocation. The Commission argued that the documents for the most part did not contain the Inuit voice because in the 1950s the communicative conditions necessary for an undistorted, free expression of the Inuit perspective were absent. From the Commission's perspective, to favor archival documents over oral histories in writing histories of the relocation would squelch the Inuit voice in the present just as it had been squelched by the illiberal communicative conditions of the 1950s. In effect, privileging archival sources threatened to perpetuate the communicative illiberalities of the $1950 \mathrm{~s}$.

By contextualizing past communications as illiberal, the Royal Commission challenged the capacity of archival sources to give voice to the Inuit. More than that, it set the stage for a ritual transformation of communicative relations, from the unfree and unequal communications between the Inuit and the state that had characterized the past to a condition of openness, equality, and freedom realized through the Commission's work. This ritual transformation revolved around the oral testimonies provided by the relocatees who were, in the framing put forward by the Commission, finally given the chance to speak freely. In contrast to the importance opponents of the claims placed on letters and other archival documents, the Commission's report found, "The oral testimony of the relocatees has provided the insight needed to recognize the long-standing misunderstandings that lie at the heart of the relocatees' complaints" (ibid.: 161). The report presented the oral testimony, not the archival documents, as a quintessential liberal communicative event-speech free of coercion in an open and equal forum.

My goal here is not to decide which context is really free, or which provides access to the true voice of the relocatees. Rather, I want to emphasize that 
"freedom" is an important contextual condition for construing speech as "voice," one that both sides in this controversy placed value on. The truth may set one free, but we see that here freedom is understood as a precondition for truth. Both sides supported their claims about which statements were true expressions of the relocatees' perspective and which were not by identifying some communications as free and others as unfree. Both sides saw the epistemological value of liberal communicative events to be intimately bound up with their moral value. For instance, for the former government officials who disputed the relocatees' claims, the value the Commission placed on the relocatees' oral testimony suppressed not only the truth but also the Euro-Canadian officials' right to be heard. Though both sides valued a liberal communicative framework, what counted as a liberal communicative event was identified and contested through the contextualizing work of rituals like the Royal Commission hearings, interpreters like Gerard Kenney, and institutions like modern bureaucratic archives that lend communicative events an aura of freedom. Freedom is not a self-evident feature of communicative contexts.

ORAL TESTIMONY AS PHATIC RITUAL: HEARING VOICES IN THE ROYAL COMMISSION HEARINGS

When the relocatees provided their accounts of the relocation, the Royal Commission, representatives of Inuit organizations, many of the participants, and much of the media contextualized the hearings within a long history of communicative illiberality, of communications suppressed and distorted, ignored and unheard. In speaking of the motivation for holding the hearings, Commission Co-Chair Rene Dussault noted, "We are struck by the fact that reports prepared for the government have relied on department files and have rarely taken the relocatees' oral testimony seriously" (in Windspeaker Staff 1993).

The media, especially the Ottawa Citizen which closely tracked the proceedings, largely echoed the Commission's view of the history of communicative relations and the need for hearings to correct past illiberalities: "The Inuit themselves were given no choice, no voice in the matter [of the relocation].... The survivors (some of whom have returned to their Hudson Bay birthplace) have over the years occasionally pressed the government for an apology, and for some measure of compensation. Successive cabinets have refused these requests, or merely ignored them" (Ottawa Citizen, 5 Mar. 1994: B6). Representatives of the Inuit Tapirisat of Canada, in prefacing the relocatees' testimony, also remarked on the inability of Inuit to speak freely in the past: "The nature of the relationship between government officials and Inuit which existed at the time of the relocation program prevented any meaningful or real consultation with Inuit as to their wishes in this matter" (RCAP 1997: record 121/11244).

Alongside depictions of a coercive and distorting communicative environment of the past, the Commission and others characterized past 
communications as having gone unheard and ignored. When they were able to voice their true feelings, "Inuit voices had been voices in the wilderness." In the words of another commentator: "At the time of the relocations, forty years before, the Inuit had been broken and demoralized. Inuit voices had been voices in the wilderness, they went unheard, often they went unsaid. Years of quiet and sometimes unintentional but nonetheless ruthless disregard had colonized their hearts, and had made them, on the surface at least, the smiling inscrutable happy-go-lucky Eskimo of Robert Flaherty's Nanook of the North" (McGrath 2006: 259). In other words, their true voice had been masked.

The Commission's hearings were presented as a transformative moment in this communicative history: "Even today, the government seems determined to repeat past mistakes. It spent much time searching its bureaucratic records for a series of reports intended to justify the move. 'This is to be contrasted,' note Tasse and Simon [who provided a preliminary report to the Royal Commission on the relocation], 'with the precious little time and effort expended to provide the Inuit relocatees with a meaningful opportunity to tell their full story.' It will take a royal commission to listen, 40 years too late" (MacQueen 1993). While much of the commentary that surrounded the hearings characterized the past as lacking communicative openness, equality, and freedom, the hearings themselves were portrayed as giving the relocatees "a meaningful opportunity to tell their full story" (RCAP 1994: 4).

Set against past communicative contexts in which the Inuit could not speak freely, the testimony in the hearings was contextualized as uncoerced and undistorted communication - the true voice of the relocatees. In the words of Zebedee Nungak, vice-president of Makivik Corporation at the time, at the close of the hearings, "The Royal Commission is one of the few independent forums left to aboriginal people in this country where we can freely present our views" (RCAP 1997: record 3475/11244). One may wonder whether Nungak really viewed the Commission as an "independent forum," given that it was established and funded by the Canadian government, but this statement echoes assessments of the Royal Commission put forward by the Commission itself, many in the media, and others (e.g., Turner 2006, ch. 4).

Moreover, while the state was depicted as having repeatedly failed to listen to the relocatees' testimony, the Royal Commission hearings were represented as a historical opportunity for the Inuit voice to finally be heard by agents of the state. Zebedee Nungak highlighted this aspect of the communicative context of the hearings in his preface to the relocatees' testimony:

At the heart of the exiles' claim is their collective memory of the conditions under which they were relocated, of the promises that were made and then broken, and of the suffering they endured.... But in order for someone to hear a story, there must be someone willing to listen to that story. And that, of course, is why we find ourselves in this impressive setting [the Chateau Laurier, where the hearings were held] — because you, the 
Royal Commission on Aboriginal Peoples, are committed to healing some of the outstanding grievances that lie heavy on the Canadian soul (Delacourt 1993).

The Royal Commission, many participants, and much of the media contextualized the hearings as an exemplary liberal communicative event which was open to the relocatees, where they were finally able to have an equal opportunity to communicate freely with the agents of the state. In contextualizing the hearings relative to a history of illiberal communicative relations, they appeared as a historical break with the past - an opening, equalizing, and freeing of communication. The relocatees' testimony marked the advance of liberal democratic communications and the starting point for "healing" Canada, ritually transforming it through this communicative event into a more liberal democratic polity.

At the center of this framing was the Royal Commission itself, which played an essential role in creating the contextual conditions necessary for this transformation. Where other government officials and institutions had been unable to achieve this degree of contact, the Royal Commission brought the Inuit relocatees communications "on record":

Until this week, these stories were passed along by the spoken word-now they are becoming part of the written record of Canada's history, as they are told to the Royal Commission on Aboriginal Peoples. These [sic] week's hearings, in effect, are a bridge between the Inuit tradition of telling history, and the white people's tradition of writing history. The relocated Inuit have been frustrated for decades by the Canadian government's inability and unwillingness to deal with their history, no matter how many times the stories were passed along. Now, this week, they are delivering their history in the white people's tradition; the commission will transcribe the stories as part of the official record (ibid.).

The Royal Commission hearings provided the communicative infrastructure - "the bridge"- that realized liberal communicative ideals presented as having gone unfulfilled for too long.

At the heart of these ideals is a vision of communicative contact between citizens and state in which both are attuned to the voices of the people - not just speaking, but speaking freely; not just speaking freely, but being heard. The front page of the Ottawa Citizen on the eve of the Royal Commission hearings set up the testimony-to-come as a moment of long delayed and much needed communicative contact between the relocatees' and the government: "It has taken 40 years, but the exiles have finally come to Ottawa to tell their heartwrenching stories to the government" (Aubry 1993). At the close of the hearings, Royal Commissioner Paul Chatrand spoke in much the same vein: "We have been able to give voice to the Inuit people by listening" (RCAP 1997: record 3547/11244). By "giving voice" to the relocatees-letting them speak freely and listening to what they had to say-the Commission brought into being what many saw as more liberal democratic communicative relations, relations in which "phatic communion" (Malinowski 1923) of citizens and state in communicative contact with one another was realized. In phatic rituals, "ties 
of union are created by a mere exchange of words" (ibid.: 478); here the relocatees spoke freely and equally and the state and other citizens listened. For supporters of the Commission's efforts, this communicative contact ritually admitted the relocatees into the communicative life of the polity, "the official record," from which they had been excluded for so long.

Here we have seen how the Royal Commission was concerned not only with unearthing a truthful representation of the past that would heal the nation, but also presented itself as a corrective for past illiberal communicative relations between citizens and state. This ritual of truth and reconciliation was portrayed as establishing communicative contact between the true voice of the relocatees and state agents. In the words of one of the commissioners, Mary Sillett, on the release of the Commission's report, "It's a happy day. After 41 years, many Inuit will be grateful that their voices were heard" (quoted in Aubry 1994).

CONCLUSION: PHATIC RITUALS AND NATION-TO-NATION RELATIONS

It has been my argument that testimonial rituals in truth and reconciliation processes are an important venue where liberal democratic ideals of communication materialize in multicultural polities. They instantiate communicative contexts that count as open, equal, and free from external coercion. In so doing, these processes create a context in which communicative relations can be ritually transformed from a past characterized as communicatively illiberal to a more liberal democratic present put on display in the here and now of truth and reconciliation hearings.

At issue is the "phatic communion" of a polity, imagined and ritually manifested as a body of voices in open, equal, and free contact with one another and the state. As phatic rituals that realize liberal democratic ideals of communication, testimonial practices and truth and reconciliation hearings "give voice" to those who have been silenced. As one commentator writes of the Royal Commission's final report:

The RCAP Report was an official version of bearing witness, given the special mantle of legitimacy that attaches to a Royal Commission, a legitimacy that was reinforced by the extensive quotations from the massive public hearings it held.... We cannot, of course, restore actual democracy to particular pasts in which it was glaringly absent for all or a portion of society. We can, however, try to give a democracy of equal recognition to the marginalized or victimized of the past. Although scanty records and shortened lives may preclude much of the detail more abundantly present for the wealthy and powerful, we can show them a concern they did not get from their contemporaries (Cairns 2003: 82$83)$.

"Extensive quotations," archives of testimonies, oral history projects, and similar outcomes of truth and reconciliation processes emblematize a polity of voices, meeting in a more open, equal, and free communicative arena. The editors of a recent volume of oral histories collected following the 
recommendation of Australia's National Inquiry into the Separation of Aboriginal and Torres Strait Islander Children from Their Families (Wilson 1997) put it this way:

One of the [Bringing Them Home Oral History] Project's important achievements is that it has provided an outlet for the voices of many who wanted to speak. It has fostered the building of a community of voices with many seen and unseen links and connections with each other and with the wider community.... The Project has created a forum for the full range of voices from this period of Australia's history, in living memory, to speak without constraint, and this book provides immediate access to that chorus of voices (Mellor and Haebich 2002: 15).

The framing of oral history and testimony as providing a "more democratised version of history" which "gives agency to all participating voices" (ibid.: 10) appears again and again in truth and reconciliation processes. In South Africa, the Truth and Reconciliation Commission's final report asserted:

Its purpose in attempting to uncover the past had nothing to do with vengeance; it had to do, rather, with helping victims to become more visible and more valuable citizens through the public recognition and official acknowledgement of their experiences. In the words of Ms. Thenjiwe Mtintso, former chairperson of the Commission on Gender Equality and currently Deputy Secretary General of the ANC [African National Congress], at the opening the [sic] Commission's hearing on women in Johannesburg, 29 July 1997: "[This hearing] is the beginning of giving the voiceless a chance to speak, giving the excluded a chance to be centred and giving the powerless an opportunity to empower themselves" (Truth and Reconciliation Commission 1998: vol. 1, ch. 5, par. 27).

In framing oral testimony given in truth and reconciliation processes as a quintessential liberal democratic communicative event, truth and reconciliation commissions present their work as essential to bringing into being communicative relations proper to liberal democracies. Such framing does not go unchallenged, however. Many former government officials felt that their voices had been silenced in the Royal Commission's report on the High Arctic Relocation and the media reporting on it. In their view, the Commission did not create a context of open, equal, and free communication, but instead worked to suppress the officials' version of events as part of a "politically correct" whitewash. To accept the Royal Commission hearings and other truth and reconciliation processes as transformative phatic rituals requires accepting that previous relations between indigenous peoples and the state were marked by communicative illiberality, and not everyone agrees with this premise.

This lack of agreement highlights the work truth and reconciliation commissions do to contextualize testimony and other communicative events as liberal and democratic. Though these are important public venues that shape perceptions about the value and characteristics of liberal communications, they are not the only ones. As liberal democracy increasingly serves as a touchstone of political legitimacy, politics plays out through competing designations of communicative contexts as open, equal, and free. The designation of 
communicative events as liberal and democratic is, then, a political and cultural matter mediated by institutions and rituals such as those I have been discussing; what counts as an open, equal, and free context of communication is hardly self-evident.

Moreover, it remains an open question whether a liberal democratic communicative framework can serve as the basis for a universally or even widely recognizable and acceptable mode of political association. The rise of communication as a concern of both liberal democratic theory and practice is, as I have noted, in part an effort to grapple with "the fact of pluralism," which has politicized the principles and legal frameworks of liberal democracies, challenging claims for their neutrality. As the fact of pluralism has challenged the notion that there is a set of universally just principles of political association, attention has shifted in liberal democracies toward communication: "Instead of grand theory, constitutional knowledge appears to be a humble and practical dialogue in which interlocutors from near and far exchange limited descriptions of actual cases, learning as they go along" (Tully 1995: 185). Such a perspective is viewed as amenable to the challenges of multiculturalism, in particular, where constitutional principles are replaced by "intercultural dialogue" in which agreement is "negotiated."

This greater emphasis on communication as the mode in which liberal democratic principles and norms can overcome the challenges of pluralism is evident not only in the communicative turn in political philosophy, but also in the sorts of rituals and institutions I have discussed here. But even with multicultural allowances for special venues where indigenous voices can speak and be heard, it is not clear that "intercultural dialogue" and "negotiation" can manage the radical challenge posed to liberal democratic ideals by "the fact of the sovereign nationhood of Aboriginal peoples." Though "intercultural dialogue" opens a space where it becomes possible for "Aboriginal voices [to] shape the normative discourses used in contemporary legal and political discourses of rights, sovereignty, and nationhood" (Turner 2013: 104), we must question whether the communicative forms of intercultural dialogue and negotiation are compatible, ultimately, with "the fact of sovereignty."

The framing of indigenous testimony in truth and reconciliation hearings as the liberalization and democratization of communication elides one of the major issues posed by the Supreme Court's Delgamuukw decision: the finding that oral histories must be accommodated as a special communicative right flowing from Aboriginal rights more generally. The Supreme Court limited this right, saying that it must not "strain the Canadian legal and constitutional structure," but this special right points toward a communicative relationship grounded not in liberal democratic principles but in the fact of First Nations' sovereignty. From this perspective, oral histories should be heard, not in the interest of opening, equalizing, and freeing communication in a liberal, multicultural polity, but rather because they communicate "Aboriginal 
world views [that] create legitimate legal and political systems" (ibid.: 105) that are sovereign and must be dealt with as such by the Canadian state.

It remains unclear whether the turn to communication in liberal democratic theory and practice can resolve the challenges posed by legal, political, and cultural pluralism. But phatic rituals such as truth and reconciliation processes and testimonial practices have emerged as one prominent and potent way in which such challenges and their resolution are being framed in contemporary liberal multicultural polities.

\section{REFERENCES}

Apel, K-O. 1990. Is the Ethics of the Ideal Communication Community a Utopia? In S. Benhabib and F. Dallmayr, eds., The Communicative Ethics Controversy. Cambridge: MIT Press, 23-59.

Asch, M. and C. Bell. 1994. Definition and Interpretation of Fact in Canadian Aboriginal Title Litigation: An Analysis of Delgamuukw. Queen's Law Journal 19, 2: 50350.

Aubry, J. 1993. Stories from Exile; Inuit Tell Commission of Lies, Broken Promises. Ottawa Citizen, 6 Apr.: A1.

Aubry, J. 1994. Inuit Threaten Court Action over Relocation of Families; Royal Commission Urges Amends for 'Coercive' Move. Ottawa Citizen, 14 July: A1.

Bashir, B. and W. Kymlicka. 2008. Introduction: Struggles for Inclusion and Reconciliation in Modern Democracies. In W. Kymlicka and B. Bashir, eds., The Politics of Reconciliation in Multicultural Societies. Oxford: Oxford University Press, 1-24.

Bauman, R. and J. Sherzer. 1989. Introduction. In R. Bauman and J. Sherzer, eds., Explorations in the Ethnography of Speaking. 2d ed. Cambridge: Cambridge University Press, 6-17.

Benhabib, S. 1996. Towards a Deliberative Model of Democratic Legitimacy. In S. Benhabib, ed., Democracy and Difference: Contesting the Boundaries of the Political. Princeton: Princeton University Press, 67-94.

Berger, Thomas R. 1977. Northern Frontier, Northern Homeland: The Report of the Mackenzie Valley Pipeline Inquiry. 2 vols. Ottawa: Minister of Supply and Services Canada.

Berton, Pierre. 1994. What's the Real Truth about the Inuit Relocation? Toronto Star, 16 Apr.: L3.

Bloch, M. 1953. The Historian's Craft. New York: Vintage Books.

Borrows, J. 2001. Listening for a Change: The Courts and Oral Tradition. Osgoode Hall Law Journal 39, 1: 1-38.

Botman, H. R. and R. M. Petersen, eds. 1996. To Remember and to Heal: Theological and Psychological Reflections on Truth and Reconciliation. Cape Town: Human \& Rousseau.

Buur, L. 2002. Monumental Historical Memory: Managing Truth in the Everyday Work of the South African Truth and Reconciliation Commission. In D. Posel and G. Simpson, eds., Commissioning the Past: Understanding South Africa's Truth and Reconciliation Commission. Johannesburg: Witwatersrand University Press, 66-93.

Cairns, A. 2003. Coming to Terms with the Past. In J. Torpey, ed., Politics and the Past: On Repairing Historical Injustices. Lanham, Mass.: Rowman and Littlefield, 63-90.

Clifford, J. 1988. Identity in Mashpee. In The Predicament of Culture. Cambridge: Harvard: University Press, 277-346.

Couldry, N. 2010. Why Voice Matters: Culture and Politics after Neoliberalism. London: Sage Publications. 
Delacourt, S. 1993. Inuit Story a Sad Chapter in Canada's History; Royal Commission Hears Tales of Despair from Natives Relocated North to the High Arctic. Globe and Mail, 6 Apr.: A8.

Duranti, A. and C. Goodwin, eds. 1992. Rethinking Context: Language as an Interactive Phenomenon. Cambridge: Cambridge University Press.

Fishkin, J. S. 1995. The Voice of the People: Public Opinion and Democracy. New Haven: Yale University Press.

Fortune, J. R. 1993. Construing Delgamuukw: Legal Arguments, Historical Argumentation, and the Philosophy of History. University of Toronto Faculty of Law Review 51, 1: 80-117.

Fraser, N. 1990. Rethinking the Public Sphere: A Contribution to the Critique of Actually Existing Democracy. Social Text 25/26: 56-80.

Grant, S. 1991. A Case of Compounded Error. Northern Perspectives 19, 1: 3-29.

Grant, S. 1993. Inuit Relocations to the High Arctic 1953-1960: Errors Exposed. Ottawa: Submission to the Royal Commission on Aboriginal Peoples.

Gunther, M. 1992. The 1953 Relocations of the Inukjuaq Inuit to the High Arctic: A Documentary Analysis and Evaluation. Ottawa: Department of Indian Affairs and Northern Development.

Gutmann, A. and D. Thompson. 2004. Why Deliberative Democracy? Princeton: Princeton University Press.

Ha, Tu Thanh. 2000. Crisis Inspired Many Native People. Globe and Mail, 11 July: A6.

Habermas, J. 1979. What Is Universal Pragmatics? In Communication and the Evolution of Society. T. McCarthy, trans. Boston: Beacon Press, 1-68.

Habermas, J. 1989. The Structural Transformation of the Public Sphere. T. Burger, trans. Cambridge: MIT Press.

Habermas, J. 1998. A Genealogical Analysis of the Cognitive Content of Morality. In C. Cronin and P. de Greiff, eds., The Inclusion of the Other: Studies in Political Theory. Cambridge: MIT Press, 3-46.

Hammond, M. M. 1984. Report of Findings on an Alleged Promise of Government to Finance the Return of Inuit at Resolute and Grise Fiord to Their Original Homes at Port Harrison (Inukjuak) and Pond Inlet. Ottawa: Department of Indian and Northern Affairs Canada.

Henderson, J. and P. Wakeham. 2013. Introduction. In J. Henderson and P. Wakeham, eds., Reconciling Canada: Critical Perspectives on the Culture of Redress. Toronto: University of Toronto Press, 3-27.

Hickling Corporation. 1990. Assessment of the Factual Basis of Certain Allegations Made before the Standing Committee on Aboriginal Affairs Concerning the Relocation of Inukjuak Inuit Families in the 1950s. Ottawa: Department of Indian Affairs and Northern Development.

Indian Chiefs of Alberta. 2011 [1970]. Citizens Plus. Aboriginal Policy Studies 1, 2: $188-281$.

Ivison, D. 2002. Postcolonial Liberalism. Cambridge: Cambridge University Press.

Jakobson, R. 1960. Closing Statement: Linguistics and Poetics. In T. A. Sebeok, ed., Style in Language. Cambridge: MIT Press, 350-77.

Kingwell, M. 1995. A Civil Tongue: Justice, Dialogue, and the Politics of Pluralism. University Park: Pennsylvania State University Press.

Kritz, N. J., ed. 1995. Transitional Justice. 3 vols. Washington, D.C.: United States Institute of Peace Press.

Lerche, C. O III. 2000. Truth Commissions and National Reconciliation: Some Reflections on Theory and Practice. Peace and Conflict Studies 7, 1: 1-20. 
Macpherson, C. B. 1962. The Political Theory of Possessive Individualism. Oxford: Oxford University Press.

MacQueen, K. 1993. A Road to Hell Paved by Ottawa. Vancouver Sun, 2 Mar.: A13.

Malinowski, B. 1923. The Problem of Meaning in Primitive Languages. In C. K. Ogden and I. A. Richards, eds., The Meaning of Meaning. London: Routledge, 451-510.

Marcus, A. R. 1992. Out in the Cold: The Legacy of Canada's Inuit Relocation Experiment in the High Arctic. Copenhagen: International Working Group for Indigenous Affairs.

McGrath, M. 2006. The Long Exile: A Tale of Inuit Betrayal and Survival in the High Arctic. New York: Alfred A. Knopf.

Mellor, D. and A. Haebich, eds. 2002. Many Voices: Reflections on the Experiences of Indigenous Child Separation. Canberra: National Library of Australia.

Merlan, F. 1998. Caging the Rainbow: Places, Politics, and Aborigines in a North Australian Town. Honolulu: University of Hawaì Press.

Minow, M. 1998. Between Vengeance and Forgiveness: Facing History after Genocide and Mass Violence. Boston: Beacon Press.

Mofina, R., K. Jaimet and S. Korah. 2001. World Will Hear Aboriginal Voices: PM Chretien Promises to Allay Fears of Marginalization at April Summit. Ottawa Citizen, 30 Mar.: A5.

Monet, D. and Skanu'u. 1992. Colonialism on Trial: Indigenous Land Rights and the Gitksan and Wet'suwet'en Sovereignty Case. Philadelphia: New Society Publishers.

Mouffe, C. 2000. The Democratic Paradox. New York: Verson.

Norris, P. and D. Zinnbauer. 2002. Giving Voice to the Voiceless: Good Governance, Human Development \& Mass Communications. United Nations Development Programme, Human Development Report Office, Occasional Paper.

Parekh, B. 2000. Rethinking Multiculturalism: Cultural Diversity and Political Theory. Cambridge: Harvard University Press.

Posel, D. 2008. History as Confession: The Case of the South African Truth and Reconciliation Commission. Public Culture 20, 1: 119-41.

Povinelli, E. A. 2002. The Cunning of Recognition: Indigenous Alterities and the Making of Australian Multiculturalism. Durham: Duke University Press.

RCAP. 1994. The High Arctic Relocation: A Report on the 1953-55 Relocation. Ottawa: Canada Communication Group.

RCAP. 1996a. Looking Forward, Looking Back. Ottawa: Report of the Royal Commission on Aboriginal Peoples, vol. 1.

RCAP. 1996b. Renewal: A Twenty-Year Commitment. Ottawa: Report of the Royal Commission on Aboriginal Peoples, vol. 5.

RCAP. 1996c. People to People, Nation to Nation: Highlights from the Report of the Royal Commission on Aboriginal Peoples. Ottawa: The Royal Commission on Aboriginal Peoples.

RCAP. 1997. For Seven Generations: An Information Legacy of the Royal Commission on Aboriginal Peoples. CD-ROM. Ottawa: Libraxus Inc.

Rorty, R. 1991. Solidarity or Objectivity? In Objectivity, Relativism, and Truth. Cambridge: Cambridge University Press, 21-34.

Rotberg, R. I. 2000. Truth Commissions and the Provision of Truth, Justice, and Reconciliation. In R. I. Rotberg and D. Thompson, eds., Truth versus Justice: The Morality of Truth Commissions. Princeton: Princeton University Press, 3-21.

Royte, Elizabeth. 2007. Trail of Tears. Review of Melanie McGrath's The Long Exile: A Tale of Inuit Betrayal and Survival in the High Arctic. New York Times Book Review, 8 Apr.: 10. 
Sanders, L. M. 1997. Against Deliberation. Political Theory 25, 3: 347-76.

Schaffer, K. and S. Smith. 2004. Human Rights and Narrated Lives: The Ethics of Recognition. New York: Palgrave Macmillan.

Schlozman, K. L., S. Verba, and H. E. Brady. 2012. The Unheavenly Chorus: Unequal Political Voice and the Broken Promise of American Democracy. Princeton: Princeton University Press.

Silverstein, M. and G. Urban, eds. 1996. Natural Histories of Discourse. Chicago: University of Chicago Press.

Soberman, D. 1991. Report to the Canadian Human Rights Commission on the Complaints of the Inuit People Relocated from Inukjuak and Pond Inlet to Grise Fiord and Resolute Bay in 1953 and 1955. Ottawa: Canadian Human Rights Commission.

Taylor, C. 1992. The Ethics of Authenticity. Cambridge: Harvard University Press.

Taylor, C. 1994. The Politics of Recognition. In A. Gutmann, ed., Multiculturalism: Examining the Politics of Recognition. Princeton: Princeton University Press, 25-73.

Teitel, R. G. 2000. Transitional Justice. Oxford: Oxford University Press.

Truth and Reconciliation Commission. 1998. Truth and Reconciliation Commission of South Africa Report. 5 vols. Cape Town: Juta.

Tully, J. 1995. Strange Multiplicity: Constitutionalism in an Age of Diversity. Cambridge: Cambridge University Press.

Tully, J. 2002. The Unfreedom of the Moderns in Comparisons to Their Ideals of Constitutional Democracy. Modern Law Review 65, 2: 204-28.

Turner, D. 2006. This Is Not a Peace Pipe: Toward a Critical Indigenous Philosophy. Toronto: University of Toronto Press.

Turner, D. 2013. On the Idea of Reconciliation in Contemporary Aboriginal Politics. In J. Henderson and P. Wakeham, eds., Reconciling Canada: Critical Perspectives on the Culture of Redress. Toronto: University of Toronto Press, 100-14.

Wallot, J-P. and N. Fortier. 1998 [1996]. Archival Science and Oral Sources. In R. Perks and A. Thomson, eds., The Oral History Reader. London and New York: Routledge, 365-78.

Weissbrodt, D. and C. de la Vega. 2007. International Human Rights Law: An Introduction. Philadelphia: University of Pennsylvania Press.

Wilson, R. 1997. Bringing Them Home: Report of the National Inquiry into the Separation of Aboriginal and Torres Strait Islander Children from Their Families. Meredith Wilkie, ed. Sydney: Human Rights and Equal Opportunity Commission.

Wilson, R. A. 2001. The Politics of Truth and Reconciliation in South Africa. Cambridge: Cambridge University Press.

Windspeaker Staff. 1993. Commission to Hear from Relocated Inuit Elders. Windspeaker 10, 26: 3. At: www.ammsa.com/node/9252 (accessed 16 July 2014).

Young, I. M. 2000. Inclusion and Democracy. Oxford: Oxford University Press. 
Abstract: The truth and reconciliation commissions of Latin America and Africa are paradigms of transitional justice, often regarded as part of the process of transitioning from authoritarian to democratic rule. But truth commissions are also common in first-world settler states, which raises the question of what "transition" such commissions effectuate in Canada, Australia, and the United States. This paper examines the efforts of Canada's Royal Commission on Aboriginal Peoples to resolve a controversy over a government relocation of Inuit families in the 1950s for which the relocatees were demanding compensation. Concurrent with historical controversies in the Canadian courts concerning Aboriginal rights and title, the historical controversy over the relocation raised questions about the Canadian state's ability to "hear the voices" of First Nations people, who objected that their accounts of the past had been disregarded by government-contracted historians and courts alike. I argue that the Royal Commission's efforts to hear the voices of Inuit relocatees, showcased in nationally televised hearings, was a phatic ritual in which communicative contact between marginalized citizens and the state was ritually established. The ritual was presented as a remedy for failures to achieve phatic communion among citizens and state - a condition of communicative contact held up as essential to the realization of liberal democratic ideals. The work of the Royal Commission and other truth commissions highlights the growing prominence of communication, particularly liberal communicative events construed as "open," "equal," and "free," as a concern of both theory and practice in liberal democratic polities. 